\title{
In Vitro Activity of Brazilian Strains of the Predatory Fungi Arthrobotrys spp. on Free-living Nematodes and Infective Larvae of Haemonchus placei
}

\author{
APS Gomes ${ }^{+}$, ML Ramos*, RS Vasconcellos*, JR Jensen**, \\ MCR Vieira-Bressan**, JV Araujo*
}

\begin{abstract}
Departamento de Parasitologia, Instituto de Ciências Biológicas, Universidade Federal de Minas Gerais, 31270-901 Belo Horizonte, MG, Brasil *Departamento de Veterinária, Universidade Federal de Viçosa, Viçosa, MG, Brasil **Departamento de Parasitologia, Instituto de Ciências Biomédicas, Universidade de São Paulo, São Paulo, SP, Brasil
\end{abstract}

In vitro tests were carried out to assess the activity of 26 Brazilian isolates of predatory fungi of the genus Arthrobotrys on a free-living nematode (Panagrellus sp.) and on infective larvae of Haemonchus placei, a parasitic gastrointestinal nematode of cattle. The results showed that the free-living nematode Panagrellus sp. was the most preyed upon, compared to H. placei, for all the fungal treatments. Also, variable predatory capacity was observed for different fungal isolates belonging to the same genus when applied to different nematode species.

Key words: predatory fungi - Arthrobotrys - nematodes - Haemonchus placei

Biological control using microorganisms is a promising alternative to control parasitic nematodes. Organisms such as fungi, bacteria, viruses, protozoa and nematodes among others, have been identified as parasites or predators of nematodes (Van Gundy 1985). Nematode-destroying fungi produce traps along the hyphae. The development of these structures represents the fungus response to the presence of nematodes or to substances derived from them or to the presence of several other compounds of biological origin, being also induced by adverse culture conditions such as water and/or nutrient deficiency (Balan \& Gerber 1972). Hypha differentiation can occur within $24 \mathrm{~h}$ and various trapping structures can be produced (Pramer 1964). Six main types of traps are known (Gray 1988). Predatory fungi of the genus Arthrobotrys produce tridimensional nets, consisting of one to three cells, covered by adhesive material (Barron 1977). Regardless of the trap type, the entrapped nematode fights to free himself, unsuccessfully (Barron 1975). The free-living nematode Panagrellus sp. is used in several laboratories around the world as a model for different studies, being used as a bait for isolation as well as in pre-

\footnotetext{
${ }^{{ }^{+} \text {Corresponding author. Fax: }}+55-31-499.2829$. E-mail: Alessandragomes@homenet.com.br Received 28 January 2000 Accepted 6 June 2000
}

dation tests of nematophagous fungi. Gomes et al. (1997) showed in trap tests using various nematodes that Panagrellus was more susceptible to predation by all the fungal isolates of genus Monacrosporium. This work aimed to compare the activity of isolates of the nematode-trapping fungus Arthrobotrys on the free-living nematode Panagrellus and the infective larvae of cattle parasitic nematode Haemonchus placei.

\section{MATERIALS AND METHODS}

Infective larvae (L3) of $H$. place $i$ were supplied by the Department of Parasitology of the University of São Paulo (USP).

Panagrellus (free-living nematodes) was originated from the Department of Phytopathology of the Federal University of Viçosa (UFV).

In order to obtain nematodes without faecal bacteria and fungi, they were washed ten times in distilled water by centrifugation for $3 \mathrm{~min}$ at 1,000 rpm. H. placei $\mathrm{L} 3$ was later stored at $4{ }^{\circ} \mathrm{C}$ for three days, in a solution containing $0.05 \%$ streptomycin sulphate, $0.05 \%$ cloramphenicol and $0.05 \%$ amphotericin $\mathrm{B}$, and the washing process with distilled water was repeated as described above. Panagrellus was stored at room temperature for one day, and washed the same way as $H$. placei.

The nematodes were counted using an optical microscope (10X), taking three $10 \mu \mathrm{l}$ aliquots, measuring the average and extrapolating the total volume.

Twenty six isolates of predatory fungi of the genus Arthrobotrys (Table) were kept in test tubes 
TABLE

Arthrobotrys isolates, its culture and local of origin

\begin{tabular}{|c|c|c|c|}
\hline Isolates & & City/State in Brazil & Crop \\
\hline A 74 & A. conoides & Dourados/MS (1991) & Corn \\
\hline A $125 b$ & A. oligospora & Rondonópolis/MT (1991) & Seringa $^{a}$ \\
\hline A $51 b$ & A. robusta & Matipó/SP (1991) & Soybean \\
\hline A 241 & A. conoides & Papanduva/SC (1993) & Garlic \\
\hline A $39 a$ & A. robusta & Viçosa/MG (1990) & Onion \\
\hline A 134 & A. robusta & Ipeúma/SP (1992) & Corn \\
\hline A279 & A. superba & Iraí de Minas/MG (1993) & Soybean \\
\hline A 72 & A. oligospora & Dourados/MS (1991) & Soybean \\
\hline A 35 & A. robusta & Atalaia/PR (1990) & Unknown \\
\hline A 40 & A. conoides & Jaguapitã/SP (1990) & Unknown \\
\hline A 32 & A. conoides & Jaguapitã/SP (1990) & Unknown \\
\hline A 31 & A. robusta & Jaguapitã/SP (1990) & Unknown \\
\hline A 144 & A. musiformes & Manaus/AM (1992) & Banana \\
\hline A 266 & A. conoides & Curitibanos/SC (1993) & Garlic \\
\hline A 265 & A. robusta & Flores da Cunha/RS (1993) & Garlic \\
\hline A 183 & A. oligospora & Cajuri/MG (1992) & Citrus \\
\hline A 39d & A. oviformis & Viçosa/MG (1991) & Onion \\
\hline A 46 & A. superba & S. Vicente Ferrer/PE (1991) & Banana \\
\hline A 38 & A. robusta & Viçosa/MG (1990) & Corn \\
\hline A 58 & A. conoides & Viçosa/MG (1991) & Okra \\
\hline A $32 \mathrm{c}$ & A. superba & Viçosa/MG (1990) & Palm tree \\
\hline A $110 b$ & A. oligospora & Lambari/MG (1991) & Beijo $^{b}$ \\
\hline A $75 a$ & A. robusta & Dourados/MS (1991) & Coffee \\
\hline A 151 & A. conoides & Uberlândia (1992) & Corn \\
\hline A $121 b$ & A. oviformis & Arinos/MG (1991) & Forest \\
\hline A 78 & A. conoides & Visc. do Rio Branco/MG (1990) & Rice \\
\hline
\end{tabular}

$a$ : a Brazilian rubber tree; $b$ : tropical flower

containing $2 \%$ potato-dextrose-agar ( $2 \%$ PDA) at $4^{\circ} \mathrm{C}$ in a dark environment. These isolates comprised eight $A$. robusta isolates (A31, A35, A38, A39, A51, A134, A75a and A265); eight $A$. conoides isolates (A32, A40, A58, A74, A78, A151, A241 and A266); four isolates of $A$. oligospora (A72, A110b, A125b and A183); two isolates of A. oviformis (A39d and A121b); two isolates of A. superba (A32c, A279 and A46) and one isolate of A. musiformis (A 144), originated from soils in several Brazilian localities (Table). Culture discs were removed from Petri dishes of $8.5 \mathrm{~cm}$ in diameter, containing $20 \mathrm{ml}$ of $2 \%$ PDA culture medium. The fungi grew on these dishes for seven days at $27^{\circ} \mathrm{C}$ in the dark, $7 \mathrm{~mm}$ diameter mycelium discs were removed from the PDA fungal culture edges, and transferred to Petri dishes containing $2 \%$ water-agar medium ( $2 \%$ WA) containing $1 \%$ gentamycin (one drop $/ 100 \mathrm{ml}$ medium). These dishes were kept in an incubator at $27^{\circ} \mathrm{C}$ for five days in the dark. On the 6 th day, $1 \mathrm{ml}$ suspension containing $500 \mathrm{H}$. placei L3 or Panagrellus sp. was individually added to these dishes. Three replications were performed for each treatment. The dishes were kept in the dark at $27^{\circ} \mathrm{C}$. Every two days the dishes were checked (40x) and the captured nematodes counted.

The results were analyzed by descriptive analysis of panels.

\section{RESULTS}

Results in the Figure show that of all tested isolates, A183 was the most effective fungus against the nematodes of both groups. Against Haemonchus, A144, A32c, A46, A58, A51b and A183 compared favorably over the remaining fungi and isolates in the assay. However, the Panagrellus freeliving nematodes were found more affected than the cattle parasitic nematode $H$. place $i$ to all tested fungus species and isolates. In the final tests, no differences were found in the degree of the freeliving nematodes infected by the various fungal isolates. Isolates A144 and A183 were more effective against $H$. placei, especially during the first days, while isolates A35 and A241 were quite effective for $H$. place $i$ during the last reading days. 


\section{DISCUSSION}

The significance of the in vitro tests like the ones here reported is better understood when considered that free-living and cattle parasitic nematodes are found in close association in environment and that such tests can lead not only to fungus isolates more effective against the cattle than the freeliving nematodes. Our results, however, indicated that the available isolates preyed more free-living Panagrellus sp. than the cattle nematode H. placei. Besides, variable predatory capacity can occur when different fungal isolates of the same genus are incubated with different species of nematodes.

Gomes et al. (1997) showed the in vitro efficacy of predacious fungi isolates on phytonematodes, free-living nematodes and parasitic nema-

\section{Panagrellus sp.}

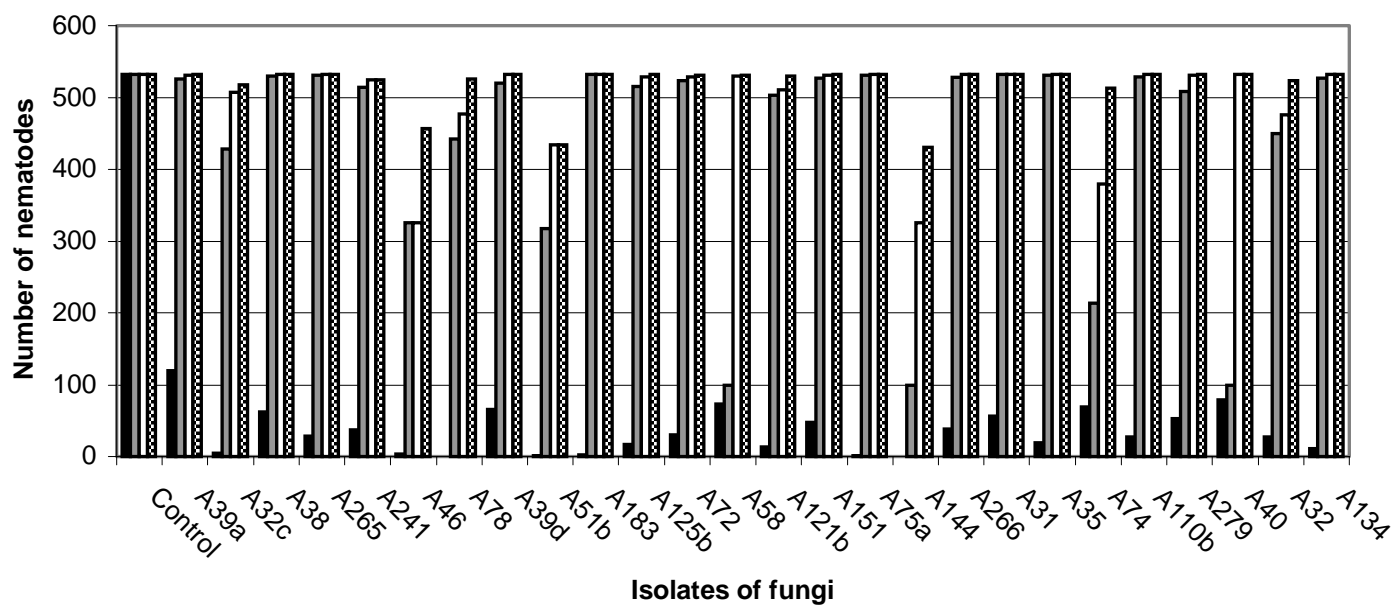

Day 1 aDay 2 aDay 3 obay 4

Haemonchus placei

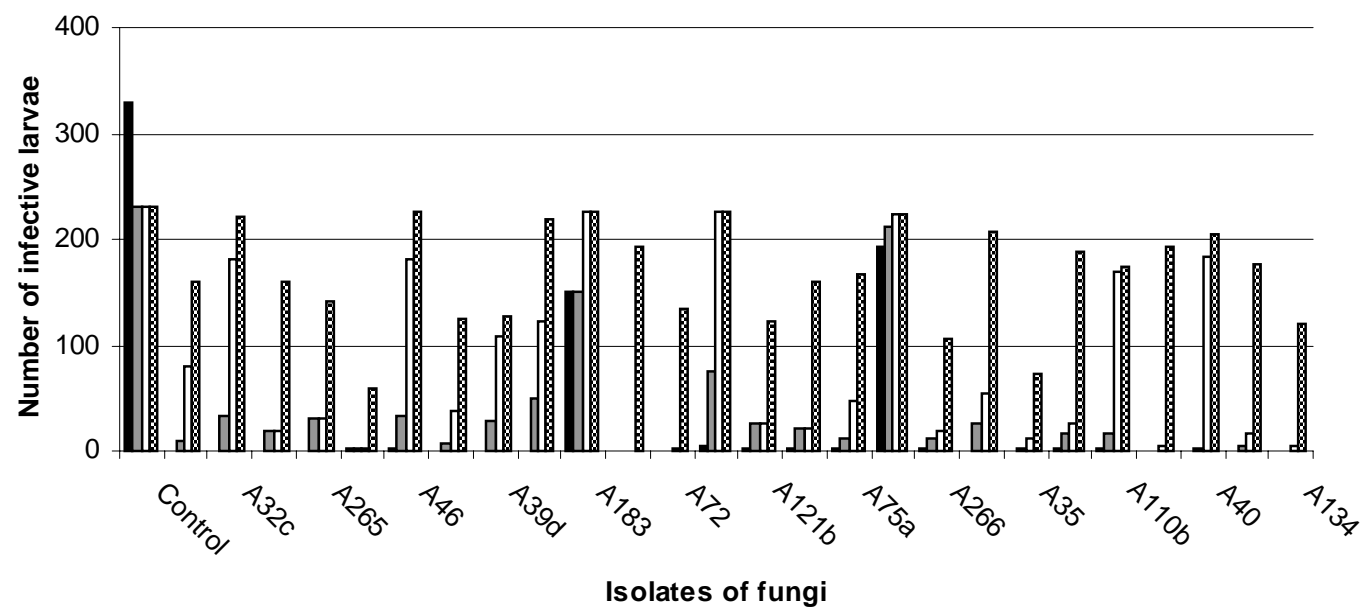

Day $1 \square$ Day $2 \square$ Day 3 Day 4

Susceptibility of nematodes to predation by fungi. Data are reported as number of nematodes trapped on days 1 to 4 after 500 nematodes were exposed to Arthrobotrys robusta (isolates A31, A35, A38, A39a, A51b, A134, A75a and A265), A. conoides (isolates A32, A40, A58, A74, A78, A151, A241 and A266), A. oligospora (isolates A72, A110b, A125b and A183), A. superba (A32c, A279 and A46), A. oviformis (A39d, A121b) and A. musiformis (A144). Data are the means of measurements in triplicate. Note that the controls are variable. 
todes of cattle (Cooperia punctata and H. placei), and in vivo biological control of bovine parasites by nematode-trapping fungi (Gomes 1998). Araújo et al. (1998) tested and confirmed the viability of A. robusta isolate in the biological control of bovine gastrointestinal nematode parasites.

In vitro tests continue to be possible in studies with nematophagous fungi, but they have limitations. They usually overestimate the activity of an agent by not allowing the nematode to escape or by not reproducing the rather common interferences found in soil and changes in the environment. Nevertheless, they have advantages such as a small physical space and shorter evaluation time. Moreover, there is a higher control that the fungus-nematode interaction is indeed taking place.

The Arthrobotrys isolates studied can be used as agents in the biological control of nematodes, becoming an useful tool to solve the problems regarding helminthosis, but further studies are necessary for selection of isolates with little or no damage to the soil microfauna.

\section{REFERENCES}

Araújo JV, Gomes APS, Guimarães MP 1998. Biological control of bovine gastrointestinal parasites in southeastern by the nematode-trapping fungus
Arthrobotrys robusta. Rev Bras Parasitol Vet 2: 117-122.

Balan J, Gerber N 1972. Attraction and killing of the nematode Panagrellus redivivus by the predacious fungus Arthrobotrys dactyloides. Nematology 18: 163-173.

Barron GL 1975. Detachable adhesive knobs in Dactylaria. Trans Br Mycol Soc 65: 311.

Barron GL 1977. The Nematode-destroying Fungi, Canadian Biological Publications, Guelph, 140 pp.

Gomes APS 1998. Controle Biológico in Vivo de Nematódeos Parasitos Gastrintestinais de Bovinos pelo Fungo Arthrobotrys robusta e Atividade in Vitro de Isolados do Fungo Monacrosporium sobre Nematódeos, MSc Thesis, Federal University of Viçosa, Viçosa, Brasil, 82 pp.

Gomes APS, Araújo JV, Ribeiro RCF 1997. Differential in vitro pathogenicity of predatory fungi of the genus Monacrosporium for phytonematodes, freeliving nematodes and parasitic nematodes of cattle. Braz J Med Biol Res 32: 79-83.

Gray NF 1988. Fungi attacking vermiform nematodes. In GO Poinar Jr, HB Jansson (eds), Diseases of Nematodes, Vol. II, CRC Press, Boca Raton, p. 3-38.

Pramer D 1964. Nematode-trapping fungi. Science 144: 382-388.

Van Gundy SD 1985. Biological control of nematodes. In MA Hoy, DC Herzog (eds), Biological Control in Agricultural IPM Systems, Vol. I, Academic Press, New York, p. 476-478. 